\title{
Entrepreneurial Emotions of Business and Non-Business Students in Higher Learning Institutions: Same or Different?
}

\author{
Nor Hafiza Othman ${ }^{1,2}$, Norasmah Othman ${ }^{1, *}$, Noor Hasni Juhdi ${ }^{3}$ \\ ${ }^{1}$ Faculty of Education, Universiti Kebangsaan Malaysia, 43600 Bangi, Selangor, Malaysia
${ }^{2}$ Faculty of Entrepreneurship and Business, Universiti Malaysia Kelantan, 16100 Kota Bharu, Kelantan, Malaysia \\ ${ }^{3}$ Faculty of Economics and Management, Universiti Kebangsaan Malaysia, 43600 Bangi, Selangor, Malaysia
}

Received October 11, 2020; Revised November 25, 2020; Accepted December 13, 2020

\begin{abstract}
Cite This Paper in the following Citation Styles
(a): [1] Nor Hafiza Othman, Norasmah Othman, Noor Hasni Juhdi, "Entrepreneurial Emotions of Business and Non-Business Students in Higher Learning Institutions: Same or Different?, "Universal Journal of Educational Research, Vol. 8, No. 12B, pp. 8248-8254, 2020. DOI: 10.13189/ujer.2020.082629.
\end{abstract}

(b): Nor Hafiza Othman, Norasmah Othman, Noor Hasni Juhdi (2020). Entrepreneurial Emotions of Business and Non-Business Students in Higher Learning Institutions: Same or Different?. Universal Journal of Educational Research, 8(12B), 8248-8254. DOI: 10.13189/ujer.2020.082629.

Copyright $\bigcirc 2020$ by authors, all rights reserved. Authors agree that this article remains permanently open access under the terms of the Creative Commons Attribution License 4.0 International License

\begin{abstract}
Entrepreneurial emotion is a new study that is evolving in entrepreneurship education. Emotions affect the capacity of a person to cope with ambiguity in making judgments and decisions. This study aims to examine whether there is a difference between entrepreneurial positive emotions and entrepreneurial negative emotions of both business and non-business students in higher learning institutions. This quantitative study involved 477 final year students in public universities, comprising 214 business students, and 243 non-business students. The results show the entrepreneurial positive emotions are different among business students and non-business students, while the entrepreneurial negative emotions are the opposite. The mean score for business students in entrepreneurial positive emotions was higher compared to non-business students. These findings reflect that the entrepreneurial knowledge and skills acquired through entrepreneurship education have enhanced their confidence and ability to organize or use their emotions more effectively in starting a business. Besides that, the results show the negative emotions of students in starting a business are not influenced by their study program. All students take into account their negative emotions in making an action to start a business. In addition, students who have entrepreneurial potential will use their emotions as much as possible in making a decision. Therefore, this study contributes to the knowledge of entrepreneurial emotions that involve
\end{abstract}

positive and negative emotions among university students in entrepreneurship education.

Keywords Entrepreneurial Emotion, Positive Emotion, Negative Emotion, Entrepreneurship Education

\section{Introduction}

A new study has recently drawn researchers' attention is emotions in entrepreneurship education. This is explained by [1], where today's research begin to examine how a person "feels", as opposed to what they "think". Students who enjoy studying will spend more time in the classroom [2]. In other words, inactive and interactive entrepreneurship education can influence the individual's interest in engaging in entrepreneurship. According to [3], a person's emotions and behaviours can be influenced when making a decision, due to the existence of external and internal factors. He explained that the factors include the information that they obtained, and the evaluation that they made on an action or decision. Therefore, the study of emotions is important in developing entrepreneurial potential because emotions precede a person's assessment of their likelihood of successfully carrying out entrepreneurial tasks and activities $[4,5,29]$. 
Besides that, higher learning institutions (HLI) play an important role in ensuring that entrepreneurship education will grow the capacity of students and inspire them to participate in entrepreneurial practices, and eventually make them pursue entrepreneurship as a career. Accordingly, entrepreneurship education is implemented either explicitly or informally through curriculum development or entrepreneurship programmes. In Malaysian context, entrepreneurship education was introduced as one of the core courses for all students at tertiary level, starting in 2013. Previously, the offer of formal entrepreneurship education was not emphasised and it depended on the university's choice, of whether implementing it in compulsory, core, or elective courses. Therefore, Malaysian entrepreneurship education has undergone a very significant change, and has become the main agenda of the country.

However, the involvement of students and graduates in entrepreneurship is still low [8], while various entrepreneurial activities and exposures have been given to them by the government. Furthermore, the percentage of unemployed graduates is also increasing each year [9]. This phenomenon is possibly happening due to the emotional effects of the students in doing entrepreneurial activity, particularly at the early stage of businesses. This is in line with an inductive study performed by [10], that potential entrepreneurs or entrepreneurs experience anxiety during entrepreneurial process at different stages. In other words, if the experience is meaningful, hence, it can stimulate positive emotions. Meanwhile, when individuals go through less meaningful and negative experiences, these will stimulate negative emotions.

Besides that, [11] said that the appraisal of circumstances can lead to positive or negative emotions. In this context, the circumstances can be attributed to the students 'entrepreneurial learning'. Thereby, entrepreneurship education that is not encouraging and does not evoke enthusiasm can cause university students to feel uninterested to venture into entrepreneurship. In addition, previous scholars recognized the study of emotions, especially in the field of psychology [12] but it is still missing in the field of entrepreneurship education $[6,7]$. This indicates that not only the cognitive component is stressed via entrepreneurship education, but the emotional component should also be emphasized because it affects the evaluation and decision of the students in starting a business. Therefore, this study investigates whether there are differences in the effects of entrepreneurial emotion, including positive and negative emotions among both business and non-business students in higher learning institutions.

\section{Literature Review}

Entrepreneurial emotions refer to effects, emotions, feelings, or moods [13]. They added that entrepreneurship creates a great emotion in terms of time strain, ambiguity, and the extent of personal feelings. This is parallel with [14], who said that emotions affect mental functions including assessments, moods, and feelings. This is supported by [12] who that anticipated emotions will affect the actions to be taken today and the future. In this context, appraisal theory of emotion can interpret the event or situation as well as what caused the situation. According to [15], emotions arise from an individual's interpretation and explanation for a given situation. Thus, their judgment (or appraisal) of a situation, event or object can determine or contribute to emotional reaction that responds to it. Therefore, anticipated emotions have the advantage that influences behaviour, and the exposure of entrepreneurship education is important since it affects their emotions towards entrepreneurship.

Moreover, emotions are formed from external stimuli that shape individual experiences [16]. Such experiences can eventually shape the personality of the individual, especially in responding to a behaviour. In other words, if the experience is meaningful, then it can stimulate positive emotions. Otherwise, when an individual goes through less meaningful and negative experiences, these will stimulate negative emotions. Furthermore, [17] asserted that individuals with negative personalities exhibit high negative emotions. This is because negative emotions will affect the perception to assess the received stimuli. This situation will affect the formation of individual personality especially in decision making. In this study, entrepreneurial emotions are referred to as anticipated entrepreneurial positive emotions and entrepreneurial negative emotions in starting a business.

Positive emotions are associated with motivation, performance, creativity, and effort for future-oriented tasks [18] that can increase the likelihood of success in the field of entrepreneurship [11,19]. This means, having positive emotions will help the effectiveness of an individual either in their career or life. Positive emotions such as happiness and joy influence the activation of tendencies in a performed assessment, and it has a significant relationship with the decision to self-employ $[20,21]$. In this study, entrepreneurial positive emotions are referred to feelings that is expected to please students to respond or do an entrepreneurial activity to start a business.

Besides that, negative emotions can reduce self-efficacy to act, which becomes an obstacle in performing an entrepreneurial activity $[12,19]$. This means that high negative emotions can contribute to lower self-efficacy or capability and this can be a barrier to entrepreneurial action. Individuals who have negative emotions towards entrepreneurship will be interpreted as difficulty performing entrepreneurial activity and this will be an obstacle for them to start a business [22,33]. This can be due to the feeling of a high degree of ambiguity and 
confusion in the individual. This is in line with [23], where individuals with high levels of anxiety are more sensitive to fear compared to individuals with low levels of anxiety. Therefore, in this study, entrepreneurial negative emotions refer to a feeling that is expected to make it impossible for students to respond or do an entrepreneurial activity to start a business.

Through the findings of a study by [24], innovation orientation in entrepreneurial activities for engineering students is higher than those of business students'. Furthermore, engineering students also rated themselves as being less positive on some personal characteristics that are associated with entrepreneurship, having less interaction with mentors, and having less engagement with entrepreneurial and extra-curricular activities. In addition, a study on the students' emotions who take online, and on-campus courses has been conducted [25]. The findings showed that students' positive emotions are higher than negative emotions regardless of the learning environment. However, students who took online courses reported higher levels of boredom, anxiety, and anger than students who took the courses on campus. Interestingly, positive emotions that are enjoyable are very important to students.

This is in line with the findings of [26], where positive emotions are important and they have a relationship between entrepreneurship education and students' tendency to start a business. In other words, when an individual wants to give an opinion about something, they will think of the views of others upon themselves first. So, entrepreneurship education helps students in increasing their potential and ability in doing entrepreneurial activities [7,32,36]. Besides that, [27] examined the emotion of achievement, finding that creative thought and reflection can be predicted by positive emotions, thereby encouraging academic achievement, whereas negative emotions are more correlated with lower performance levels. Therefore, the emotions of students towards entrepreneurship may either inspire or motivate them to participate in entrepreneurship, or inversely.

Indirectly, students' emotions affect their abilities to recognize and respond to entrepreneurial opportunities and subsequently perform entrepreneurial activities of starting a business. So, emotions are expected to influence an action that will be taken today and in the future $[12,28]$. In addition, research among students on entrepreneurial emotions is still minimal and similarities are still less investigated between student programs. Therefore, this study attempts to determine whether business students and non-business students vary between entrepreneurial positive emotions and entrepreneurial negative emotions. Figure 1 displays the conceptual framework that has been developed.

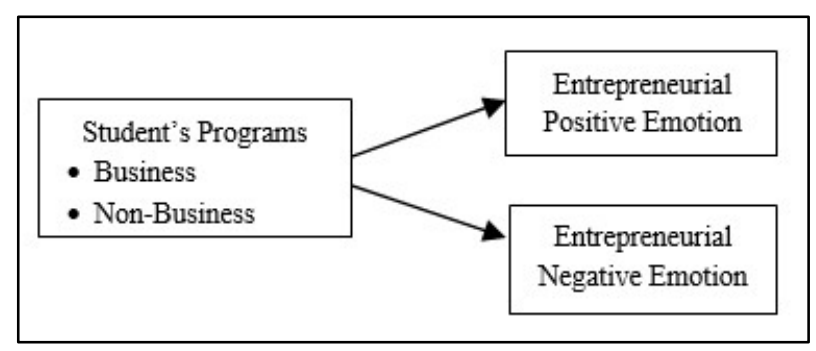

Figure 1. Conceptual Framework

\section{Methodology}

\subsection{Sample}

A total of 477 final year students from several public universities were involved in this study. This quantitative study used cross-sectional surveys through questionnaires administered by the researcher. For the study's sample, the researcher chose simple stratified and random sampling techniques. In this study, questionnaire was the main instrument which consisted of three parts. The different parts covered the profile of the respondents, entrepreneurial positive emotions, and entrepreneurial negative emotions.

The respondents responded to a seven-point scale for items of entrepreneurial positive emotion and entrepreneurial negative emotion, whereby $1=$ strongly disagree, and $7=$ strongly agree, adapted from $[12,29]$. In this context, the entrepreneurial positive emotions are the feelings that are expected to please students to start a business such as happiness, excitement, satisfaction, pride and hope. Meanwhile, entrepreneurial negative emotions are feelings that are expected to make it difficult for students to start a business such as sad, angry, scared, ashamed and worried.

\subsection{Pilot Study}

A pilot study was conducted prior to the collection of the main data to obtain the accuracy of the instruments used in the study [30]. In this study, to determine the reliability of the instrument, the researcher used internal consistency (Cronbach Alpha). Cronbach Alpha values that are less than 0.60 are low and unacceptable, values 0.60 to 0.80 are acceptable and values above 0.80 are considered good [30]. The analysis obtained that the Cronbach Alpha values for entrepreneurial positive emotions was 0.946 and entrepreneurial negative emotions was 0.942 . This indicates that the item has good internal stability, as well as usable in the actual study. 


\subsection{Data Analysis}

The information obtained from the returned questionnaire was coded, and the data were analysed using IBM SPSS Version 22 programme. In this study, descriptive and inferential statistics were used in data analysis. For descriptive statistics, frequencies and percentages have been used in describing respondents' profile. While, to test the study's hypotheses, inference statistics were used through t-test analysis. According to [35], t-test is used when to compare the mean score, on some continuous variables, for two different groups of respondents.

\subsection{Common Method Bias}

Harman's single factor test was conducted to check for any common method bias when the data were collected from a single source [31]. The results showed that 41.6 percent of the variance was explained by the first factor, which was $<50$ percent as recommended by [31]. Additionally, two factors explained the total variance $(82.75 \%)$ and the value was greater than 50 percent. Therefore, the common method bias does not carry any problem in this analysis

\section{Results}

\subsection{Respondent Profile}

Table 1 shows the demographics of the respondents where $24.3 \%$ of the students were males, and $75.7 \%$ of them were females. A total of 214 students majored in business, while 243 students were not business major. Besides that, all the students had taken entrepreneurship courses in their first year of study, and most of them (78.3\%) had experiences in business. As for the chosen career, $57.7 \%$ wanted to be employed (salary earner) and
$42.3 \%$ chose entrepreneur as career after graduation.

Table 1. Profile of Respondents

\begin{tabular}{|c|c|c|}
\hline & Frequency & Percentage (\%) \\
\hline Gender & & \\
Male & 128 & 26.8 \\
Female & 349 & 73.2 \\
\hline Courses & & \\
Business & 214 & 44.9 \\
Non-Business & 243 & 55.1 \\
\hline Business Experience & & \\
Yes & 347 & 72.7 \\
No & 130 & 27.3 \\
\hline Career of choice & & \\
Employee & 275 & 56.7 \\
Self-employee & 202 & 42.3 \\
\hline
\end{tabular}

\subsection{Entrepreneurial Positive Emotion}

H1: There is a difference between the entrepreneurial positive emotions of business and non-business students.

Based on Table 2, there is a significant difference between the entrepreneurial positive emotions of business students compared to non-business students, $\mathrm{t}(475)=3.35$, $\mathrm{p}<0.05, \mathrm{LB}=0.172, \mathrm{UP}=0.662$. In fact, the mean score for business students (mean=4.92, $\mathrm{SD}=1.32$ ) is high compared to non-business students (mean $=4.50, \mathrm{SD}=1.38$ ). Therefore, the research hypothesis is supported $(\mathrm{p}<0.05)$.

\subsection{Entrepreneurial Negative Emotion}

$\mathrm{H} 2$ : There is a difference between the entrepreneurial negative emotions of business and non-business students.

Based on Table 3, there is no significant difference between the entrepreneurial negative emotions of business students compared to non-business students, $\mathrm{t}$ (440) $=-0.344, \mathrm{p}>0.05, \mathrm{LB}=-0.319, \mathrm{UP}=0.224$. The mean value also indicates that the score obtained has low difference between business students (mean $=4.30, \mathrm{SD}=1.55$ ) and non-business students (mean $=4.34, \mathrm{SD}=1.44)$. Thus, the research hypothesis is not supported ( $\mathrm{p}>0.05$ ).

Table 2. T-test of Entrepreneurial Positive Emotion

\begin{tabular}{|c|c|c|c|c|c|c|c|c|}
\hline & Courses & Mean & $\begin{array}{c}\text { Standard } \\
\text { Deviation }\end{array}$ & $\mathrm{t}$ & Df & p-value & $\begin{array}{c}\text { Lower Bound } \\
\text { (LB) }\end{array}$ & $\begin{array}{c}\text { Upper Bound } \\
\text { (UP) }\end{array}$ \\
\hline \multirow{2}{*}{$\begin{array}{c}\text { Positive } \\
\text { Emotion }\end{array}$} & Business & 4.92 & 1.32 & & & & & \\
\cline { 2 - 9 } & Non-Business & 4.50 & 1.38 & 3.35 & 475 & $0.001 *$ & 0.172 & 0.662 \\
\hline
\end{tabular}

$* \mathrm{p}<0.05$

Table 3. T-test of Entrepreneurial Negative Emotion

\begin{tabular}{|c|c|c|c|c|c|c|c|c|}
\hline & Courses & Mean & $\begin{array}{c}\text { Standard } \\
\text { Deviation }\end{array}$ & $\mathrm{t}$ & $\mathrm{df}$ & $\mathrm{p}$-value & $\begin{array}{c}\text { Lower Bound } \\
\text { (LB) }\end{array}$ & $\begin{array}{c}\text { Upper Bound } \\
\text { (UP) }\end{array}$ \\
\hline \multirow{2}{*}{$\begin{array}{c}\text { Negative } \\
\text { Emotion }\end{array}$} & Business & 4.30 & 1.55 & \multirow{2}{*}{-0.344} & 440 & 0.731 & -0.319 & 0.224 \\
\cline { 2 - 9 } & Non-Business & 4.34 & 1.44 & -249 & \\
\hline
\end{tabular}

$\mathrm{p}>0.05$ 


\section{Discussion}

The first findings showed that there was a significant difference between the entrepreneurial positive emotions of business students compared to non-business students. The mean score for business students was higher compared to non-business students. This showed that the emotions of the business students in starting a business were more positive. This could have happened due to the expertise or skills gained through entrepreneurship education that strengthened their capacity and willingness to venture into entrepreneurship [12,29]. Exposure to various forms of knowledge of entrepreneurship can increase the students' awareness about entrepreneurship [7,32]. Indirectly, students' emotions affect their ability to respond to entrepreneurial opportunities and subsequently act in performing entrepreneurial activities to start a business. Thus, with positive emotions, a person can control the situation and survive with the actions taken in the future, especially when they face challenges at the initial stage of their businesses.

This is reinforced by [28] who said that that individuals who can organize and use their emotions effectively will be more likely to trust their abilities to become entrepreneurs. Indirectly, they will be more effective and competitive in seeking more opportunities to start a new business or grow an existing business. This means, in difficult circumstances, those with entrepreneurial potential can use their emotions and provide a competitive advantage that contributes to a greater entrepreneurial success. Thus, they will be more optimistic and believe that what is to be achieved is within their control.

Furthermore, the findings also show that for business students and non-business students, entrepreneurial negative emotions are the same. Although the average results obtained by non-business students are higher than business students, the difference is infinitesimal. This shows that all students take their emotions into account and they are more cautious about acting and starting a company. Negative emotions can decrease the self-efficacy of acting, which is an obstacle to entrepreneurship $[12,19,27]$. Based on a study by [33], a negative emotion such as fear of failure is a psychological factor that does not motivate university graduates to start a business, despite having the opportunity. This condition is caused by negative emotions that make them feel scared even before trying it. Therefore, it is not surprising that the students are very cautious in choosing entrepreneurship as a career option.

In addition, emotions play an important role in entrepreneurial process when conducting business activities and making decisions in the selection of entrepreneurial career. This is recognized by [34], where emotion is considered as a major factor in the decision-making process of one's career. This is clarified when emotions influence people to make decisions and carry out an entrepreneurial activity $[11,12]$. Besides that, this is aligned with appraisal theory of emotion that involves personal interpretations of situation in determining emotional reaction. This is supported by [15], where emotions arise from an individual's interpretation and explanation for a given situation. Therefore, their judgment (or appraisal) of a situation, event, or object can determine or contribute to emotional response.

\section{Conclusions}

Emotions lie within a person and affect more than the process of entrepreneurship alone, where the person doing the business is also affected. In other words, when someone makes a decision, they will think about how they feel about it. This describes entrepreneurial positive emotions including a pleasant response to an action, while entrepreneurial negative emotions will decrease the effectiveness of doing something. So, the emotional reaction of the students can be their driving force or an obstacle to entrepreneurship. Due to the increasingly challenging and uncertain economic and business conditions, this needs a closer look to allow students to be more courageous in assessing business risks. Therefore, in beginning a business venture, their expression in entrepreneurial learning can influence their emotions and lead to further actions.

Overall, the findings of this study have proven that entrepreneurial positive emotion and entrepreneurial negative emotions have different concepts and roles in each assessment, or the decision made. This study provides an understanding about the comparison between entrepreneurial positive emotions and entrepreneurial negative emotions according to the students' majors. This means that students who have entrepreneurial potential will use their emotions as much as possible in any circumstances, to become more confident and believe that everything is under control. Therefore, the findings of this study contribute to the knowledge of entrepreneurial emotions that involve positive and negative emotions among university students in entrepreneurship education at tertiary level.

\section{REFERENCES}

[1] J. C. Hayton, M. Cholakova. The role of affect in the creation and intentional pursuit of entrepreneurial ideas, Entrepreneurship Theory and Practice, Vol. 36, No. 1, pp. 41-68, 2012. DOI: 10.1111/j.1540-6520.2011.00458.x.

[2] R. S. Lazarus. How emotions influence performance in competitive sports, Sport Psychologist, Vol. 14, No. 3, pp. 229-252, 2000. DOI: 10.1123/tsp.14.3.229

[3] S. S. Khan. Developing Positive Emotion through Affective Design for Interactive Information Seeking, Seventh 
BCS-IRSG Symposium on Future Directions in Information Access (FDIA), pp. 1-4, 2017.

[4] R.A. Baron. The role of affect in the entrepreneurial process, Academy of Management Review, Vol. 33, No. 2, pp. 328-340, 2008. DOI: 10.5465/amr.2008.31193166.

[5] L. A. Zampetakis, M. Lerakis, K. Kafetsions, V. Moustakis. Anticipated emotions towards new venture creation: A latent profile analysis of early stage career starters. The International, Journal of Management Education, Vol. 14, No. 1, pp. 28-38, 2016.

[6] G. Nabi, F. Linan, F. Alain, A. Walmsley. The impact of entrepreneurship education in higher education: A systematic review and research agenda. Academy of Management Learning and Education, Vol. 16, No. 2, pp. 277-299, 2017. DOI: 10.5465/amle.2015.0026.

[7] N. H. Othman, N. Othman. A systematic review on entrepreneurship education in higher learning institutions in Southeast Asia, Universal Journal of Educational Research, Vol. 7, No. 11, pp. 2406-2416, 2019. DOI: 10.13189/ujer.2019.071118.

[8] Ministry of Higher Education. Malaysia Education Development Plan 2015 - 2025, 2015.

[9] Ministry of Education. Tracer Study Report 2018, 2019.

[10] G. Cacciotti, J. C. Hayton, J. R. Mitchell, A. Giazitzoglu. A reconceptualization of fear of failure in entrepreneurship, Journal of Business Venturing, Vol. 3, No. 3, pp. 302-325, 2016. DOI: 10.1016/j.jbusvent.2016.02.002.

[11] B.L. Fredrickson. Positive emotions broaden and build: Advances in experimental social psychology, Academic Press, Vol. 47, pp. 1-53, 2013. DOI: 10.1016/B978-0-12-40 7236-7.00001-2.

[12] D. L. Joseph, D. A. Newman. Emotional intelligence: An integrative meta-analysis and cascading model, Journal of Applied Psychology, Vol. 95, No. 1, pp. 54 -78, 2010. DOI: 10.1037/a0017286

[13] M. S. Cardon, M. D. Foo, D. Shepherd, J. Wiklund. Exploring the heart: Entrepreneurial emotion is a hot topic, Entrepreneurship Theory and Practice, Vol. 36, No.1 pp. 110, 2012. DOI: 10.1111/j.1540-6520.2011.00501.x

[14] J. D. Mayer, C. D. Cobb. Educational policy on Emotion Intelligence: Does it make sense? Educational Psychology Review, Vol. 12, No.2 pp. 163-183, 2000.

[15] T. Imada, P.C. Ellsworth. Proud Americans and lucky Japanese: Cultural differences in appraisal and corresponding emotion. Emotion, Vol. 11, No.2, pp. 329345, 2011. DOI: 10.1037/a0022855.

[16] E. Komulainen, K. Meskanen, J. Lipsanen, J. M. Lahti, P. Jylhä, T. Melartin, J. Ekelund. The effect of personality on daily life emotional processes, Vol. 9, No. 10, e110907, 2014. DOI: 10.1371/journal.pone.0110907.

[17] K. D. Baumeister, C. Vohs, N. Dewall, L. Zhang. How emotion shapes behavior: Feedback, anticipation, and reflection, rather than direct causation. Personality and Social Psychology Review, Vol. 11, No. 2, pp. 167-203, 2007. DOI: $10.1177 / 1088868307301033$.

[18] E. Tenney, J. Poole, E. Diener. Subjective well-being and organizational performance, In Research in Organizational Behavior, Greenwich, CT, JAI Press, 2016.

[19] L. M. Welpe, M. Sporrle, D. Grichnik, T. Michl, D. B. Audretsch. Emotions and opportunities: The interplay of opportunity evaluation, fear, joy, and anger as antecedent of entrepreneurial exploitation, Entrepreneurship Theory \& Practice, Vol. 36, pp. 69-96, 2012. DOI: 10.1111/j.1540-6520.2011.00481.x.

[20] S. Inanova, T. Treffers, F. Langerak. Emotional paths leading to opportunity desirability and feasibility beliefs through controllability, International Small Business Journal, Vol. 36, No.5, pp. 546-573, 2018.

[21] B. Nikolaev, C. J. Boudreaux, L. E. Palich. Cross-country determinants of early stage necessity and opportunity-motivated entrepreneurship: Accounting for model uncertainty, Journal of Small Business Management, pp. 1-53, 2018. DOI: $10.1111 /$ jsbm. 12400 .

[22] N. H. Othman, N. Othman, N. H. Juhdi. Determining the validity and reliability of entrepreneurial emotion, Academy of Entrepreneurship Journal, Vol. 25, No. 3, pp. 1-5, 2019.

[23] A. Richards, C. French, A. J. Caider, B. S. Webb Anxiety-related bias in the classification of emotionally ambiguous facial expressions, Emotion, Vol. 2, No. 3, pp. 273-287, 2002. DOI: 10.1037/1528-3542.2.3.273.

[24] Q. Jin, S. K. Gilmartin, S. Sheppard, H. L. Chen. Comparing engineering and business undergraduate students' entrepreneurial interests and characteristics, Journal of Engineering Entrepreneurship, Vol. 6, No. 2, pp. 1-24, 2015. DOI: $10.7814 /$ jeenv6n2p1.

[25] M. Stephan, S. Markus, Z. M. Glaser. Students' achievement emotions and online learning in teacher education, Front. Educ, 4, 109, 2019. DOI: 10.3389/feduc.2019.00109.

[26] L. Li, D. Wu. Entrepreneurial education and students' entrepreneurial intention: Does team cooperation matter? Journal of Global Entrepreneurship Research, Vol. 9, No. 35, pp. 1-13, 2019. DOI: 10.1186/s40497-019-0157-3.

[27] R. Pekrun, T. Goetz, A. C. Frenzel, P. Barchfeld, R. P. Perry. Measuring emotions in students' learning and performance: the achievement emotions questionnaire (AEQ), Contemp. Educ. Psychol, Vol. 36, No. 1, pp. 36-48, 2011. DOI: 10.1016/j.cedpsych.2010.10.002.

[28] N. H. Othman, N. Othman, N. H. Juhdi. Entrepreneurship education and business opportunity exploitation: Positive emotion as mediator, Cakrawala Pendidikan, Vol. 39, No. 2, pp. 388-392, 2020. DOI: 10.21831/cp.v39i2.30102.

[29] M. D. Foo. Emotions and entrepreneurial opportunity evaluation, Entrepreneurship: Theory and Practice, Vol. 35, No. 2, pp. 375-393, 2011. DOI: 10.1111/j.1540-6520.2009. 00357.x.

[30] U. Sekaran, R. Bougie. Research Methods for Business: A Skill Building Approach, United Kingdom, John Wiley \& Sons, 2016.

[31] P. M. Podsakoff, S. B. MacKenzie, J. Y. Lee, N. P. Podsakoff. Common method biases in behavioral research: A critical review of the literature and recommended remedies, Journal of Applied Psychology, Vol. 88, No. 5, pp. 879-903, 2003. 
[32] C. Mason, M. Anderson, T. Kessl, M .Hruskova. Promoting student enterprise: Reflections on a university start-up programme, Local Economy, Vol. 35, No. 1, pp. 1-12, 2019. DOI: $10.1177 / 0269094219894907$.

[33] J. O. Ekore, O. C. Okekeocha. Fear of entrepreneurship among university graduates: A psychological analysis, International Journal of Management, Vol. 29, No. 2, pp. $515,2012$.

[34] P. L. Ackerman, M. E. Beier. Intelligence, personality, and interests in the career choice process, Journal of Career
Assessment, Vol. 11, No. 1, pp. 205-218, 2003. DOI: $10.1177 / 1069072703011002006$

[35] J. Pallant. SPSS Survival Manual, Ed.6, McGraw-Hill Education, New York, 2016.

[36] N. Othman, N.S.M. Hisam. Entrepreneurial self-efficacy and entrepreneurial intention among polytechnic students involved and not involved in entrepreneurship education, Universal Journal of Educational Research, Vol. 8, No. 10, pp. 4406 - 4415, 2020. DOI: 10.13189/ujer.2020.081007 